\title{
Investigation of an innovative PV/T-ORC system using amorphous silicon cells and evacuated flat plate solar collectors
}

\author{
Cagri Kutlu ${ }^{1}$, Jing $\mathrm{Li}^{1,2}$, Yuehong $\mathrm{Su}^{1}$, Yubo Wang ${ }^{3}$, Gang Pei $^{2}$, Saffa Riffat ${ }^{1}$ \\ ${ }^{I}$ Department of Architecture and Built Environment, University of Nottingham, University Park, Nottingham \\ $N G 72 R D, U K$ \\ ${ }^{2}$ Department of Thermal Science and Energy Engineering, University of Science and Technology of China, 96 \\ Jinzhai Road, Hefei, Anhui, 230026, China \\ ${ }^{3}$ School of Economics and Management, Hubei University of Technology, Wuhan, Hubei, 430068, China
}

\begin{abstract}
Solar-driven organic Rankine cycle (s-ORC) power generation is a promising technology with thermal storage for flexible operation to meet domestic variable electricity demand. A satisfactory efficiency of this technology can be obtained only at medium-to-high temperature, for which conventional flat plate and evacuated tube solar collectors are not suitable while solar concentrators cannot efficiently utilize diffuse solar radiation. Evacuated flat plate (EFP) collectors have recently been developed for efficient solar heat collection in the temperature range from 100 to $200^{\circ} \mathrm{C}$, suitable for the ORC system. At present, the cost of EFP collectors is relatively high and will lead to a long payback period of the s-ORC system. To increase the annual power yield and reduce the payback time, inexpensive amorphous silicon (a-Si) solar cells are proposed to be integrated into the EFP collectors. It is the first time to put forward such photovoltaics/thermal (PV/T) design combining a-Si cells and EFP collectors. Compared with polycrystalline silicon cells (poly-Si), a-Si cells may have a higher electrical efficiency at a higher operating temperature due to the thermal annealing effect and are expected to have a long lifetime without encapsulation in the vacuum environment provided by the EFP collectors. In this study, the a-Si PV/T-ORC system using EFP collectors is investigated. Transient performance analysis of a-Si PV/T-ORC is given for the weather data of two selected days. A comparison is also made with a stand-alone poly-Si PV system, poly-Si PV/T-ORC system and s-ORC system with EFP collectors alone, respectively. The results indicate that for a typical day in July, the a-Si PV/T-ORC system has the highest daily power output of $0.822 \mathrm{kWh} / \mathrm{m}^{2}, 102.3 \%$ more than the s-ORC system, $23.8 \%$ more than the stand-alone poly-Si PV system and $12 \%$ more than the poly-Si PV/TORC system, respectively.
\end{abstract}

Keywords: Solar organic Rankine cycle, Amorphous silicon cell, Photovoltaic/thermal, Evacuated flat plate collector

\footnotetext{
*First corresponding author. Jing Li, jing.li@ hull.ac.uk

*** Second corresponding author. Yuehong Su, yuehong.su@ nottingham.ac.uk
} 


\section{Introduction}

The solar-driven organic Rankine cycle (s-ORC) has a great potential for meeting the domestic electricity demand. When it is combined with thermal storage, power generation of the s-ORC can be not intermitted by fluctuation of solar radiation and even during night time. Additionally, the s-ORC allows adjustment to outputs according to the variation in domestic electricity demand [1]. A summary of work on s-ORC is shown in Table 1.

Table 1. Summary of some studies on s-ORC

\begin{tabular}{|c|c|c|c|c|c|}
\hline Type of collector & $\begin{array}{c}\text { Heat transfer } \\
\text { fluid } \\
\text { temperature }\end{array}$ & $\begin{array}{l}\text { Evaporation } \\
\text { temperature }\end{array}$ & $\begin{array}{c}\text { Overall } \\
\text { Efficiency }\end{array}$ & Reference & Notes \\
\hline \multirow{4}{*}{$\begin{array}{l}\text { Parabolic trough } \\
\text { collectors }\end{array}$} & T & $85-190^{\circ} \mathrm{C}$ & $3.6-7.9 \%$ & [2] & $\begin{array}{l}\text { Indirect steam } \\
\text { generation }\end{array}$ \\
\hline & $135-230{ }^{\circ} \mathrm{C}$ & - & $6-12 \%$ & [3] & $\begin{array}{l}\text { Combined with } \\
\text { geothermal }\end{array}$ \\
\hline & & $80-200{ }^{\circ} \mathrm{C}$ & $3-11 \%$ & [4] & $\begin{array}{l}\text { Indirect steam } \\
\text { generation }\end{array}$ \\
\hline & - & - & $12-13.5 \%$ & [5] & Evacuated \\
\hline \multirow{2}{*}{$\begin{array}{l}\text { Concentrating } \\
\text { photovoltaics }\end{array}$} & - & $90-150^{\circ} \mathrm{C}$ & $6.35-10 \%$ & [6] & $\begin{array}{l}\text { Direct steam } \\
\text { generation }\end{array}$ \\
\hline & - & $80-130^{\circ} \mathrm{C}$ & $10-15 \%$ & [7] & $\begin{array}{c}\text { Direct steam } \\
\text { generation }\end{array}$ \\
\hline \multirow{2}{*}{$\begin{array}{c}\text { Evacuated flat } \\
\text { plate } \\
\text { collectors }\end{array}$} & $180{ }^{\circ} \mathrm{C}$ & - & $9-10 \%$ & [8] & $\begin{array}{l}\text { Indirect steam } \\
\text { generation }\end{array}$ \\
\hline & - & $95-145^{\circ} \mathrm{C}$ & $4.4-7.4 \%$ & [9] & $\begin{array}{l}\text { Indirect steam } \\
\text { generation }\end{array}$ \\
\hline \multirow{3}{*}{$\begin{array}{l}\text { Evacuated tube } \\
\text { collectors }\end{array}$} & - & $95-145^{\circ} \mathrm{C}$ & $2.5-4 \%$ & [9] & Using heat-pipe \\
\hline & - & $85-120^{\circ} \mathrm{C}$ & $3.47 \%$ & {$[10]$} & $\begin{array}{c}\text { Indirect steam } \\
\text { generation }\end{array}$ \\
\hline & - & $180-200{ }^{\circ} \mathrm{C}$ & $5.5 \%$ & [11] & $\begin{array}{l}\text { Indirect steam } \\
\text { generation }\end{array}$ \\
\hline
\end{tabular}

The development of s-ORC systems is restricted by its efficiency, which is significantly lower than PV efficiency. The efficiency of solar ORC can be raised only with high temperature heat. Flat plate collectors (FPCs) and evacuated tube collectors (ETCs) are suitable for solar heat collection at temperature below $100{ }^{\circ} \mathrm{C}$. Concentrating collectors can reach higher operating temperatures, however, concentrators such as compound parabolic concentrators (CPCs) and parabolic trough collectors (PTCs) can hardly use diffuse radiation and potentially have high costs for the tracking system. To overcome the challenges, evacuated flat plate (EFP) collectors have recently been used for s-ORC applications. It's a 
relatively new and promising technology with high thermal efficiency even under low ambient temperatures and solar radiation levels. Studies on the EFP collectors in district heating and s-ORC applications have been reported. Calise et al. [8] designed and simulated a CHP system by using EFP collectors. They reported that EFP collectors can operate with over 50\% thermal efficiency in summer, and around 20\% in winter. These efficiencies are attractive values considering high operating temperatures (up to $212^{\circ} \mathrm{C}$ ). Freeman et al. [9],[12] simulated this type of collectors for solar ORC applications and concluded that their CHP unit can considerably provide power to meet electricity demand of a UK home. Kutlu et al. [13] built an annual simulation model and presented that the EFP collectors can be successfully implemented in ORC system even for low solar radiation periods. Finally, Gao et al. [14] reported that the average efficiency of practical EFP collectors is higher than $50.8 \%$ even at an operation temperature of above $100{ }^{\circ} \mathrm{C}$.

At present, the capital cost of EFP collectors is higher than that of conventional FPCs, ETCs, CPCs and PTCs. The payback period of s-ORC using EFP collectors is expected to be fairly long. In contrast, PV cells convert solar energy into electricity with an efficiency of about 8 to $25 \%$ and have reached a high degree of maturity [15]. PV technology requires very little maintenance and has low repair expenses, making this technology operationally one of the cheapest options [16]. Heat can be also supplied in the form of PV/T system, which comprises a solar collector and PV module as major components [17]. Therefore, adding solar cells to EFP collectors has the potential to reduce the payback period of the s-ORC system.

Selection of solar cells for the EFP collectors is crucial. Given the higher conversion efficiency and low cost, crystalline silicon (c-Si) cells have become the most preferred cell material in the world market. Mono-Si and poly-Si cells have 15.1 and 43.9 percent of the total solar cell production [18]. Their efficiencies vary between 15-20\%. However, crystalline cells have some drawbacks in the PV/T application. Common c-Si cells have large negative power temperature coefficients, which lie around -0.41 to $-0.50 \%{ }^{\circ} \mathrm{C}$ at maximum power point under standard test conditions. With an efficiency of $18 \%$ at $25^{\circ} \mathrm{C}$, the absolute efficiency drop can be $5 \%$ when temperature is increased to $75^{\circ} \mathrm{C}$ [19]. This reduction is expected to be sharper at higher operating temperatures [20]. Also, these cells are only suitable for operating at low temperatures, for example, producing domestic hot water [21]. Otherwise, the PV/T system will not be advantageous over side-by-side PV and solar water systems. Another drawback of the c-Si cells is that they can be easily broken in long term usage as a result of temperature fluctuation and gradient. A PV cell has a lower thermal expansion coefficient compared to aluminium and copper, which are used as absorber and substrate materials in the PV/T collectors. Since the operating temperature may vary from 0 to $80^{\circ} \mathrm{C}$ during the yearly operation [22], it is possible for c-Si cells to experience a large thermal stress and lesser PV lifetime.

Amorphous silicon (a-Si) cells, on the other hand, are ideal in the s-ORC applications. Firstly, they are widely used and are also the most developed of thin film cells. In China, more than 2.0 GW of a-Si cells can be produced annually [23], and the global market is likely to reach USD 5310.2 million by 2025 [24]. Secondly, a-Si cells are flexible. The flexibility can prevent fractions (breakup) of cells when they are coupled with aluminium, copper or other metals in a PV/T panel. Temperature fluctuations cause the metal to expand and shrink, which results in the production of tension stress on the cells. Crystalline silicon cells are weak 
in their ability to carry thermal stress resulting in their shortened lifespan, but a-Si cells may be more reliable to alleviate this issue. This flexibility facilitates its ease of integration into solar collectors. Thirdly, a-Si cells can use metals as substrate, so the thermal resistance of the PV/T module is reduced. Feasibility of PV/T with a-Si cells deposited on stainless steel has been demonstrated for medium temperature applications by more than 15 month continuous operations [25]. Finally, a-Si cells benefit from thermal annealing at high operation temperature. They have a lower conversion efficiency compared to other silicon based cells [26], which is partially caused by the Staebler-Wronski effect [27]. The photons with the photoelectron energy below the band gap of a-Si cells directly pass through the a-Si layer and cannot be absorbed by the intrinsic layer, thus contributing essentially no photocurrent and limiting the conversion efficiency of the a-Si cells [28],[29]. However, the Staebler-Wronski effect can be reversed. At a high temperature, the performance of a-Si cells is degraded fast but reaches a higher efficiency at the degraded steady state [30]. It is reported that a positive power temperature coefficient is obtained in the long term operation. For example, at the degraded steady state, the a-Si cell efficiency ratio at $90{ }^{\circ} \mathrm{C}, 50$ ${ }^{\circ} \mathrm{C}$ and $25^{\circ} \mathrm{C}$ is about $0.8,0.73,0.64$ [31]. Notably, the positive power temperature coefficient is desirable in the medium-to-high temperature applications.

In this paper, an innovative PV/T-ORC system is proposed, in which it is the first time to combine EFP collectors with a-Si cells in a PV/T panel. The advantages of the PV/T-ORC system using a-Si cells and EFP collectors can be summarized below:

- Encapsulation for the PV cells can be avoided. Operating at medium-to-high temperature is challenging to solar cells, however, it is the encapsulation rather than the solar cell that suffers from medium-to-high temperature operation. In the vacuum chamber, there is no need for encapsulation and a long lifetime of a-Si cells is expected.

- a-Si cells will benefit from thermal annealing at medium-to-high temperatures. In fact, when being heated above $150{ }^{\circ} \mathrm{C}$, a-Si cells could reverse the Staebler-Wronski effect [27].

- Thermal storage using water is adopted for flexible power generation. The storage cost is relatively low when compared with batteries.

- Combining the EFP collectors with a-Si cells can result in an increment of annual electricity yields and a significant decrement in the payback period. So, the integration is also beneficial for the s-ORC.

To prove this statement, a performance comparison is made between four different systems in this study. The models are built, and investigation of the systems has been conducted from the viewpoints of electricity output and its profile. The first one is the proposed a-Si PV/TORC system, in which the EFP collectors are covered with a-Si cells with a 0.85 cover area ratio. The second one is the s-ORC with EFP collectors alone. The third is the PV/T-ORC system using poly-Si cells. The last one is a stand-alone poly-Si PV system. These systems will be compared according to their thermal and electrical efficiencies and power outputs considering thermocline behaviour of the water tank in transient state.

\section{System Description and Thermodynamic Modelling}


In this section, descriptions of the proposed system and its counterparts will be given. The schematic of a s-ORC with EFP collectors alone is shown in Fig. 1, which is composed of a collector system, a heat storage unit and an ORC unit. A water tank is used as a heat storage unit to provide heat in a controllable way for the ORC unit. The EFP collectors are used for heating water, which is circulated from the bottom of the tank and then discharged into the top of the tank. The water tank allows the ORC unit to be driven when solar radiation is insufficient or unavailable. In the ORC unit, there are four main components namely pump, evaporator, expander and condenser.

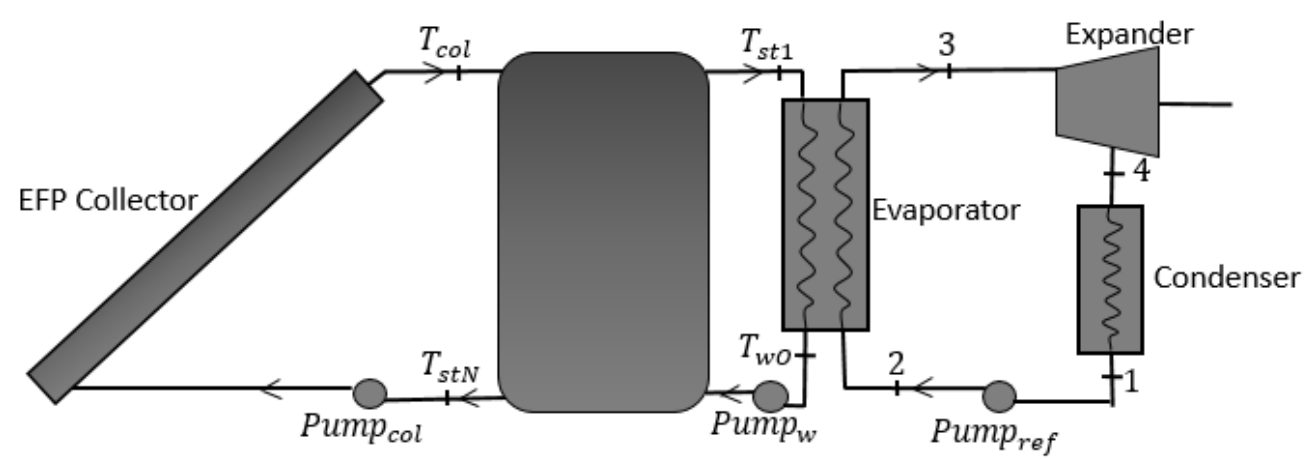

Fig. 1. Schematic view of the system

For PV/T-ORC systems, a-Si or poly-Si is integrated into the EFP collectors to form PV/T collectors. For the purpose of comparison, a stand-alone poly-Si PV system with an area same as EFP collectors is also considered.

\subsection{PV model}

In the stand-alone PV system, commonly preferred poly-Si type modules have been chosen. Electrical characteristics of the modules are taken from the manufacturer's data and presented in Table 2. The most common equation to determine the cell temperature is referring to Normal Operating Cell Temperature (NOCT). This value is given by the manufacturer and Eq. (1) is used for calculating the cell temperature [32].

$$
T_{c e l l}=T_{a}+(N O C T-20) \cdot \frac{G}{800}
$$

Photovoltaic module electrical efficiency is calculated by the most known model:

$$
\eta_{P V}=\eta_{r}\left[1-\beta_{r} \cdot\left(T_{\text {cell }}-T_{r}\right)\right]
$$

The parameters are given by manufacturers and $\eta_{r}$ indicates an efficiency at the reference temperature. Global electrical efficiency of the PV system can be calculated as Eq. (3):

$$
\eta_{g P V}=\eta_{P V} \cdot \eta_{D C-A C}
$$

where $\eta_{D C-A C}$ is conversion efficiency of DC to AC and is reported as between $80-95 \%$ depending on solar irradiance [33], [34]. For $<300 \mathrm{~W} / \mathrm{m}^{2}, \eta_{D C-A C}$ is $80 \%$. For $300 \mathrm{~W} / \mathrm{m}^{2}$ $<G<500 \mathrm{~W} / \mathrm{m}^{2}, \eta_{D C-A C}$ is $85 \%$. For $500 \mathrm{~W} / \mathrm{m}^{2}<G<800 \mathrm{~W} / \mathrm{m}^{2}, \eta_{D C-A C}$ is $90 \%$. 
For $>800 \mathrm{~W} / \mathrm{m}^{2}, \eta_{D C-A C}$ is $95 \%$. This conversion efficiency will be used in calculation of electricity output.

Table 2. Main technical specifications of a PV module [35]

\begin{tabular}{ll}
\hline PV & Specifications \\
\hline Model & Atersa A-214P \\
\hline Type & Polycrystalline Silicon \\
\hline Module efficiency, $\boldsymbol{\eta}_{\boldsymbol{r}}$ & $12.64 \%$ \\
\hline Power temperature coefficient, & $-(0.46) \% \mathrm{~K}$ \\
$\quad \boldsymbol{\beta}_{\boldsymbol{r}}$ & \\
\hline NOCT & $47^{\circ} \mathrm{C}$ \\
\hline
\end{tabular}

Regarding the a-Si cell performance, experimentally obtained results have been used [36]. Fig. 2 gives electrical efficiencies of a-Si and poly-Si cells, where the efficiency of the polySi cell is calculated from Eqs. (1)-(2) and Table 2. Fig. 2 presents that two electrical efficiency lines intercept at $98^{\circ} \mathrm{C}$; this means that using the a-Si cells in PV/T at an operation temperature of over $98{ }^{\circ} \mathrm{C}$ has a better electrical efficiency than using poly-Si cells. This figure supports the aim of the study.

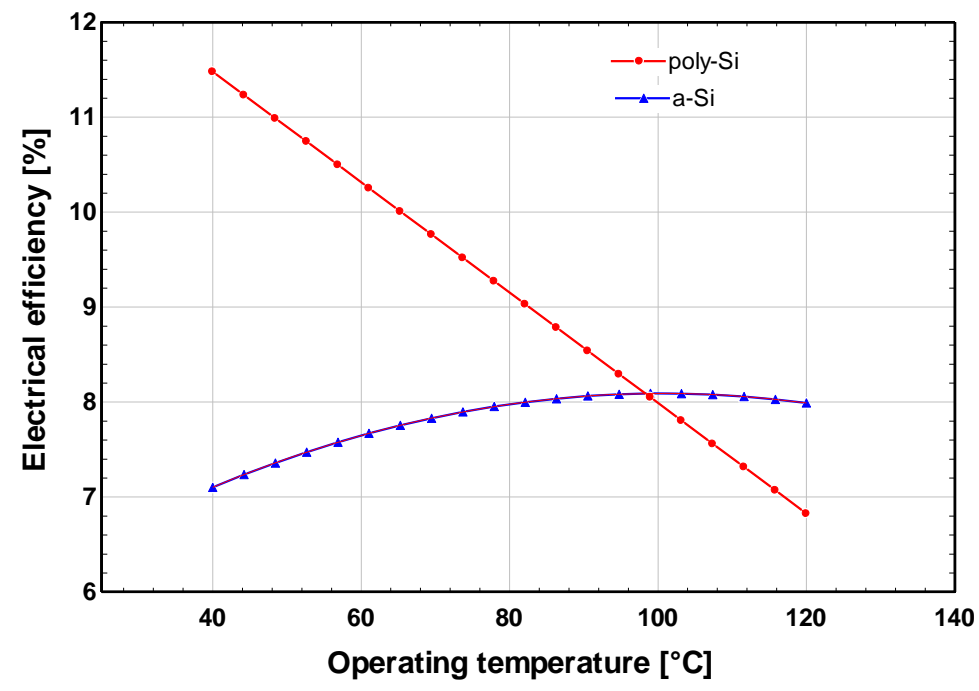

Fig. 2. Electrical efficiency of poly-Si and a-Si cells [36]

\subsection{PV/T model}

PV/T collectors are obtained by incorporating PV cells into the EFP collectors. TVP SOLAR HT-Power EFP collectors [37] are used in the s-ORC system while the PV/T collectors modified from EFP collectors are used in two PV/T-ORC systems. EFP collector structure is shown in Fig. 3. 


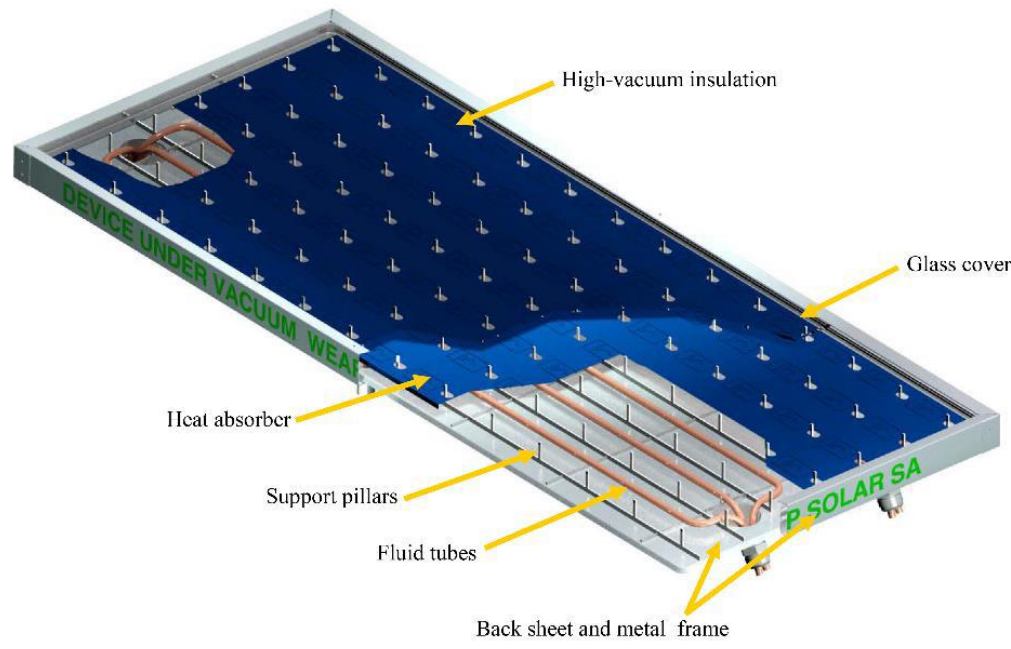

Fig. 3. Structure of EFP collector [37]

The general form thermal efficiency equation of a solar collector is given in Eq. (4):

$$
\eta_{c}=\eta_{0}-A \cdot \frac{T-T_{a}}{G}-B \cdot \frac{\left(T-T_{a}\right)^{2}}{G}
$$

where $T$ is the mean water temperature in the collector, $G$ is solar irradiance, $A$ and $B$ are heat loss coefficients. For the used EFP collectors, $\eta_{0}$ is $74.62, A$ and $B$ are 39.9 and 0.67 , respectively [12].

The power output of PV cell is calculated by Eq. (5):

$$
W_{P V}=\eta_{P V} \cdot G \cdot A_{c o l} \cdot x
$$

where $x$ indicates the cover area ratio and is taken as 0.85 . The heat collection efficiency of a $\mathrm{PV} / \mathrm{T}$ collector can be deduced [36] as :

$$
\eta_{P V T}=\eta_{c}-\eta_{P V} \cdot x
$$

where $\eta_{P V}$ is assumed as a second order equation and can be expressed by

$$
\eta_{P V} \cdot x=\eta_{P V, 0}+a \cdot T+b \cdot T^{2}
$$

Three constants in Eq. (7) can be obtained by data fitting from Fig. 2.

For PV/T collector thermal efficiency the equation can be written as

$$
\eta_{P V T}=\eta_{c, 0}^{\prime}-A^{\prime} \cdot \frac{T-T_{a}}{G}-B^{\prime} \cdot \frac{\left(T-T_{a}\right)^{2}}{G}
$$

where $\eta_{c, 0}^{\prime}, A^{\prime}$ and $B^{\prime}$ are the modified coefficients of the collector and can be given as below.

$$
\begin{gathered}
\eta_{c, 0}^{\prime}=\eta_{c, 0}-\eta_{P V, 0}-a \cdot T_{a}-b \cdot T_{a}^{2} \\
A^{\prime}=A+\left(a+2 \cdot b \cdot T_{a}\right) \cdot G
\end{gathered}
$$


By applying deductions, thermal efficiency equations for a-Si and poly-Si PV/T collectors can be obtained. It is necessary to analyse the system according to operating parameters. For this issue, conventional EFP collectors are covered with a-Si and poly-Si cells to form a-Si $\mathrm{PV} / \mathrm{T}$, poly-Si PV/T collectors, respectively, and their thermal efficiencies are determined by using Eqs. (4-11). Fig. 4 compares the thermal efficiencies according to various solar irradiance values and two operating temperatures. It is evident that the poly-Si PV/T has a higher thermal efficiency at higher operation temperatures because its reduced electrical efficiency, whereas the a-Si PV/T has less thermal efficiency due to its higher electrical efficiency at higher temperature.
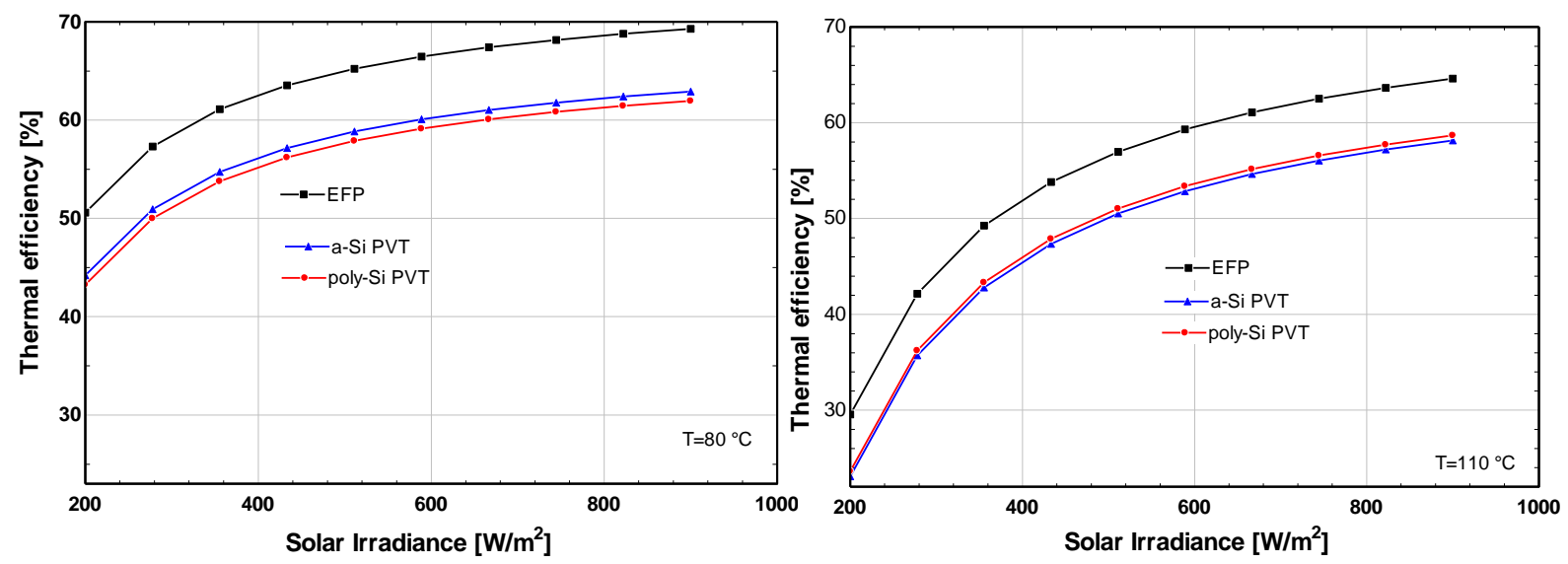

Fig. 4. Thermal efficiency comparisons for two operating temperatures

\subsection{Water tank model}

The transient performance of the heat storage unit is modelled by considering the thermocline behaviour. It is analysed using a one-dimensional temperature distribution model [38], [39], [40]. The cylinder volume has been divided into equal nodes to obtain the temperature distribution in the storage tank. An energy balance equation can be written considering the heat loss to the environment for the control volume of each node. Eqs. (12)-(14) are given for the energy balance equations of the nodes:

$$
\begin{aligned}
& M_{s t 1} \cdot c_{p, w} \cdot \frac{\partial T_{s t 1}}{\partial t} \\
& =\dot{m}_{c w} \cdot c_{p, c w} \cdot\left(T_{c o l}-T_{s t, 1}\right)+\dot{m}_{w} \cdot c_{p, w} \cdot\left(T_{s t, 2}-T_{s t, 1}\right)-U_{t} \cdot A_{s t 1} \\
& \cdot\left(T_{s t, 1}-T_{a}\right) \\
& M_{s t, i} \cdot c_{p, w} \cdot \frac{\partial T_{s t, i}}{\partial t} \\
& =\dot{m}_{c w} \cdot c_{p, c w} \cdot\left(T_{s t, i-1}-T_{s t, i}\right)+\dot{m}_{w} \cdot c_{p, w} \cdot\left(T_{s t, i+1}-T_{s t, i}\right)-U_{t} \\
& \cdot A_{s t, i} \cdot\left(T_{s t, i}-T_{a}\right)
\end{aligned}
$$




$$
M_{s t, N} \cdot c_{p} \cdot \frac{\partial T_{s t, N}}{\partial t}
$$

$$
\begin{aligned}
& =\dot{m}_{c w} \cdot c_{p} \cdot\left(T_{s t, N-1}-T_{s t, N}\right)+\dot{m}_{w} \cdot c_{p} \cdot\left(T_{w o}-T_{s t, N}\right)-U_{t} \cdot A_{s t, N} \\
& \cdot\left(T_{s t, N}-T_{a}\right)
\end{aligned}
$$

where $\dot{m}_{c w}$ and $\dot{m}_{w}$ indicate water mass flowrate coming from the collector and the evaporator respectively, $T_{w o}$ is the water temperature coming from the evaporator to the tank bottom node, $U_{t}$ indicates the thermal loss coefficient of the thermally-insulated tank.

\subsection{ORC model}

The ORC unit consists of four components and the key component is the expander as it produces electrical power for users. It was decided that a scroll type expander would be used in the analysis, because this was particularly well-adapted to small-scale Rankine cycle applications. Since the heat source temperature is not constant during operation, the system operates at off-design conditions. A semi-empirical model is put forward in a study by Lemort et al. [41]. As reported, this expander model is good for analysing the variation of the expander performance over changing conditions [42]. Expander modelling follows the same stages as in [41] and [43], i.e., 1) adiabatic supply pressure drop, 2) isobaric supply cooling down, 3) internal leakage, 4) adiabatic and reversible expansion to the adapted pressure, 5) adiabatic expansion at constant machine volume, 6) adiabatic fluid mixing and 7) isobaric exhaust heating-up or cooling down. These hypothetic stages are shown in Fig. 5 where subscript su denotes supply, amb is ambient and ex indicates exhaust. Similar to a study in [43], most of those empirical parameters in [41] are adopted in this study, while the swept volume is adjusted for different capacities of expander.

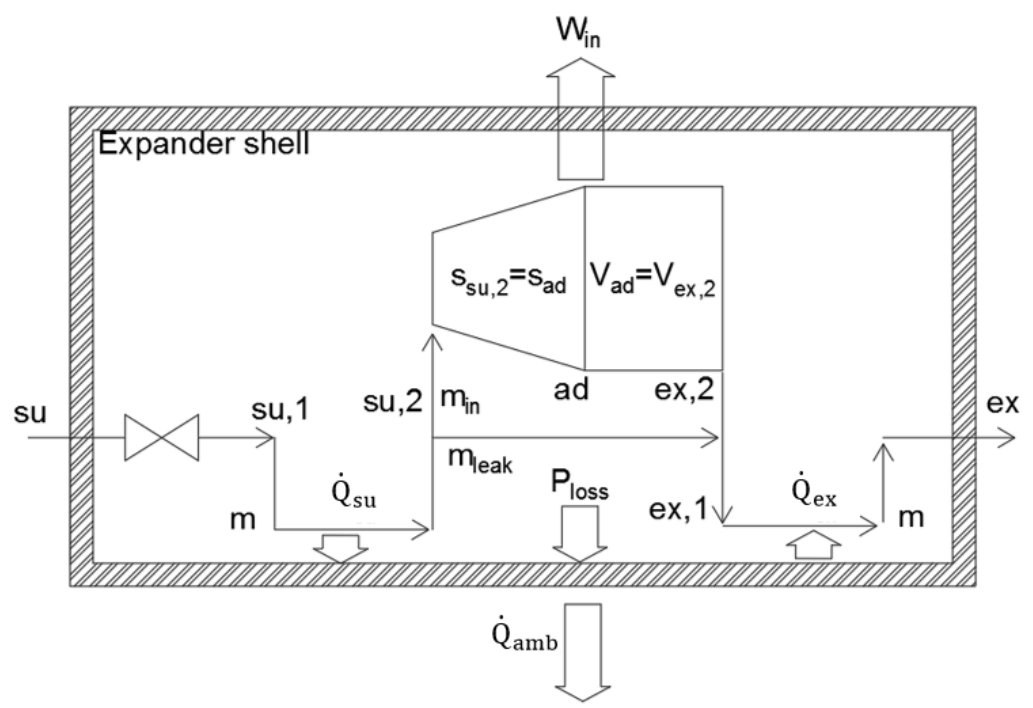

Fig. 5. Schematic view of stages of expander model proposed by [41] 
When refrigerant enters the expander, its pressure slightly reduces and mass flow rate can be given by Eq.(15)

$$
\dot{m}_{r e f}=\rho_{s u 1} \cdot A_{s u} \cdot \sqrt{2 \cdot\left(h_{s u}-h_{s u 1}\right)}
$$

where $\dot{m}_{r e f}$ is refrigerant mass flow rate at the inlet port in the scroll expander. This mass flow rate also includes leakage flows. Next step is isobaric cooling down of the refrigerant due to heat loss the shell of the expander. After that point, leakage flow rate can be determined by Eq.(16) and Eq.(17):

$$
\begin{gathered}
\dot{m}_{\text {ref }}=\rho_{s u, 2} \cdot V_{s w} \cdot \frac{N}{60}+\dot{m}_{\text {leak }} \\
\dot{m}_{\text {leak }}=\rho_{\text {leak }} \cdot A_{\text {leak }} \cdot \sqrt{2 \cdot\left(h_{\text {su, } 2}-h_{\text {leak }}\right)}
\end{gathered}
$$

where $V_{S W}$ and $N$ indicate the swept volume of the expander and rotation speed, respectively. After leakage flow leaves from the main flow, internal flow expands to the adapted pressure, which is related to built-in volume ratio $(B V R)$ of the positive replacement expanders. This is followed by a pressure drop or increase from the adapted pressure to the exit discharge pressure. This usually happens under off-design condition when the exit pressure is different from the adapted pressure. It can be either under- or over-expansion as shown in Fig. 6.
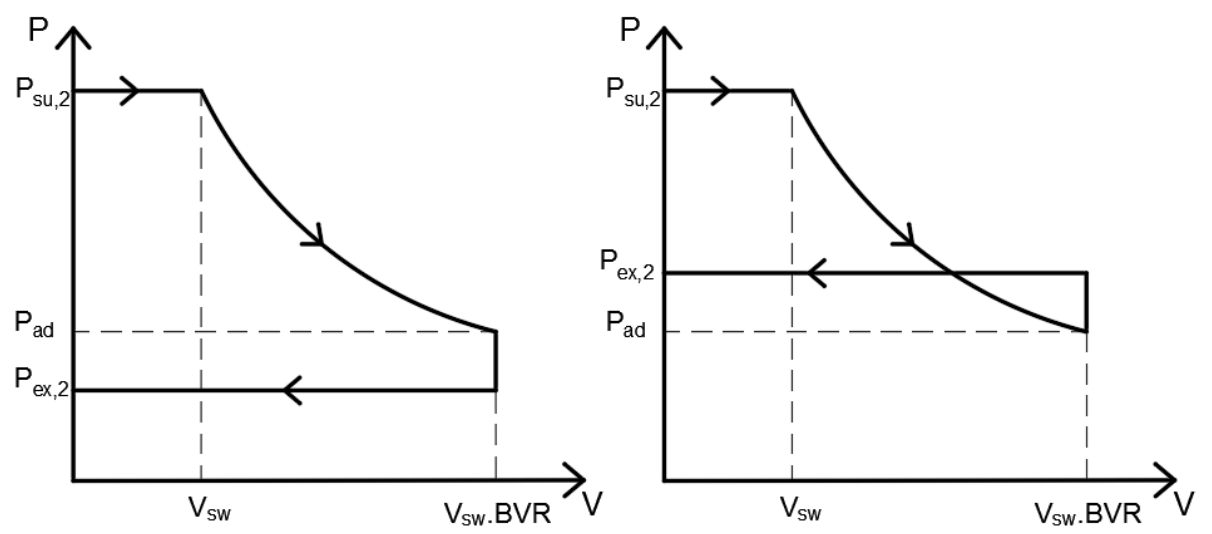

Fig. 6. Schematic of under and over expansion adapted from [43]

When those thermodynamic states are determined, internal expansion power can be found from Eq. (18):

$$
W_{\text {in }}=\left(\dot{m}_{r e f}-\dot{m}_{\text {leak }}\right) \cdot\left[\left(h_{s u, 2}-h_{a d}\right)-v_{a d} \cdot\left(P_{a d}-P_{e x, 2}\right)\right]
$$

Shaft power can be found from Eq. (19): 
The ORC evaporator is modelled according to the effectiveness-NTU method. As the temperature of the water varies with time due to solar energy supply and heat consumption by the ORC unit, a sliding pressure operation [44], [45] is implemented in the modelling, which means that the evaporation pressure is determined from the water inlet temperature. Related equations and a detailed investigation of the effects of circulation water mass flow rate on system performance is given in our previous study [1].

\subsection{Modelling of different configurations}

A simulation was conducted to compare four different systems, i.e., s-ORC, a-Si PV/T-ORC, poly-Si PV/T-ORC and stand-alone poly-Si PV. EFP collectors are employed in the s-ORC system, while for two PV/T-ORC systems, their PV/T collectors are converted from EFP collectors. Fig. 7 shows the flow chart of simulation procedure in this study, including stepby-step use of relevant equations. Firstly, a comparison of steady state performance is made between three systems containing an ORC unit. Afterwards, the transient performance of all four different systems including the stand-alone PV system are simulated and compared for weather conditions of two selected days.

For the s-ORC system, the steady-state overall efficiency is given as a ratio of electricity output relative to the received solar radiation:

$$
\eta_{\text {overall,s-ORC }}=\eta_{O R C} \cdot \eta_{c} \cdot \eta_{m e}
$$

For PV/T-ORC systems, the steady-state overall efficiency can be given from the PV efficiency and the ORC efficiency:

$$
\eta_{\text {overall,PV/T-ORC }}=\eta_{P V}+\eta_{O R C} \cdot \eta_{P V T} \cdot \eta_{m e}
$$

It is the first time that highly efficient EFP solar collectors have been proposed to couple with a-Si PV cells to produce electricity in addition to heat collection at a higher temperature. Further incorporation with a heat storage unit and an ORC unit can offer a flexibility in power generation. It is of great necessity to evaluate the system performance before constructing an expensive test rig for a whole system. It is not possible at this stage to compare the whole system simulation results with a corresponding experimental system. However, we believe the mathematical model of the whole system shall have a good level of reliability and accuracy because the key components of the modelled whole system have been 
well studied numerically or experimentally in literature, for example, as a commercial product, the efficiency formula of EFP collectors has been empirically determined according to the relevant European Standards. For poly-Si and a-Si PV cells, the well-known cell temperature-dependent electrical efficiency approach has been used. The models for heat storage tank and ORC unit have referred to several previous studies.

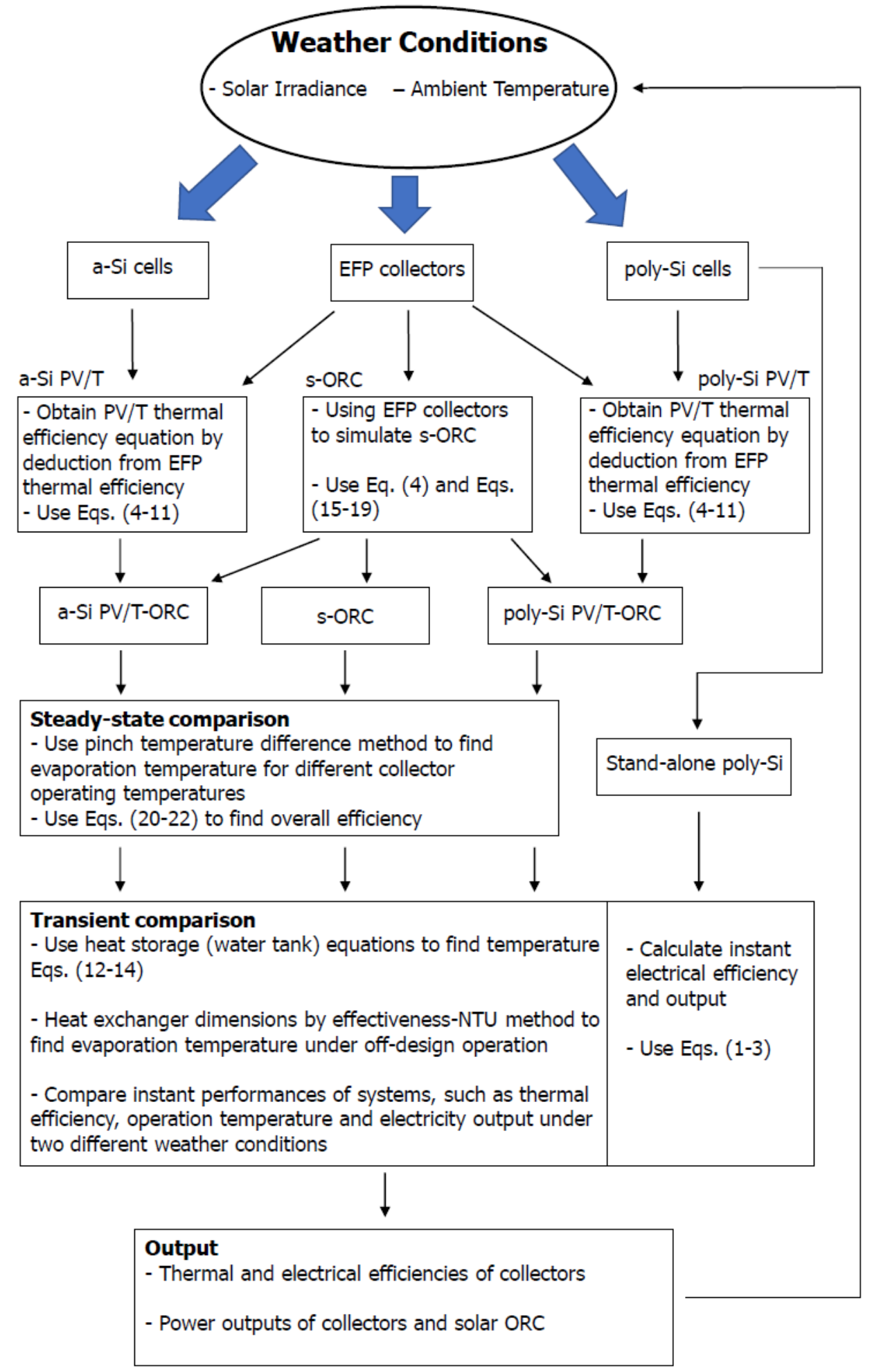

Fig. 7. Flow chart of simulation procedure 


\section{Results and discussions}

\subsection{Comparison of steady state performance}

As seen in Fig.2 and Fig.4, PV electrical performance and collector thermal performance depend on the operating conditions. In this sub-section, s-ORC and PV/T-ORC systems are compared according to their operating temperatures. To conduct this, some assumptions have been made for this sub-section only. Normally s-ORC and PV/T-ORC systems have a water tank as a heat storage to produce electricity during night, however, in this steady analysis, it is not necessary to consider the heat storage unit. Circulated water from the collector evaporates the ORC working fluid via a heat exchanger. The working fluid is heated up from a subcooled liquid to a saturated liquid which then is vaporized to a saturated vapour. This process is achieved with an optimum way by using a counter flow heat exchanger. This indirect system is analysed by the pinch temperature difference method [46]. For different collector operating temperatures, this analysis considers that the ORC evaporation temperature can be found by keeping a constant pinch temperature difference. The working fluid T-s diagram in Fig. 8 shows the pinch temperature difference between the ORC working fluid and the collector heat transfer fluid. By doing this analysis, the collector efficiency and ORC efficiency can be obtained according to operating temperatures to calculate the overall efficiency of system.

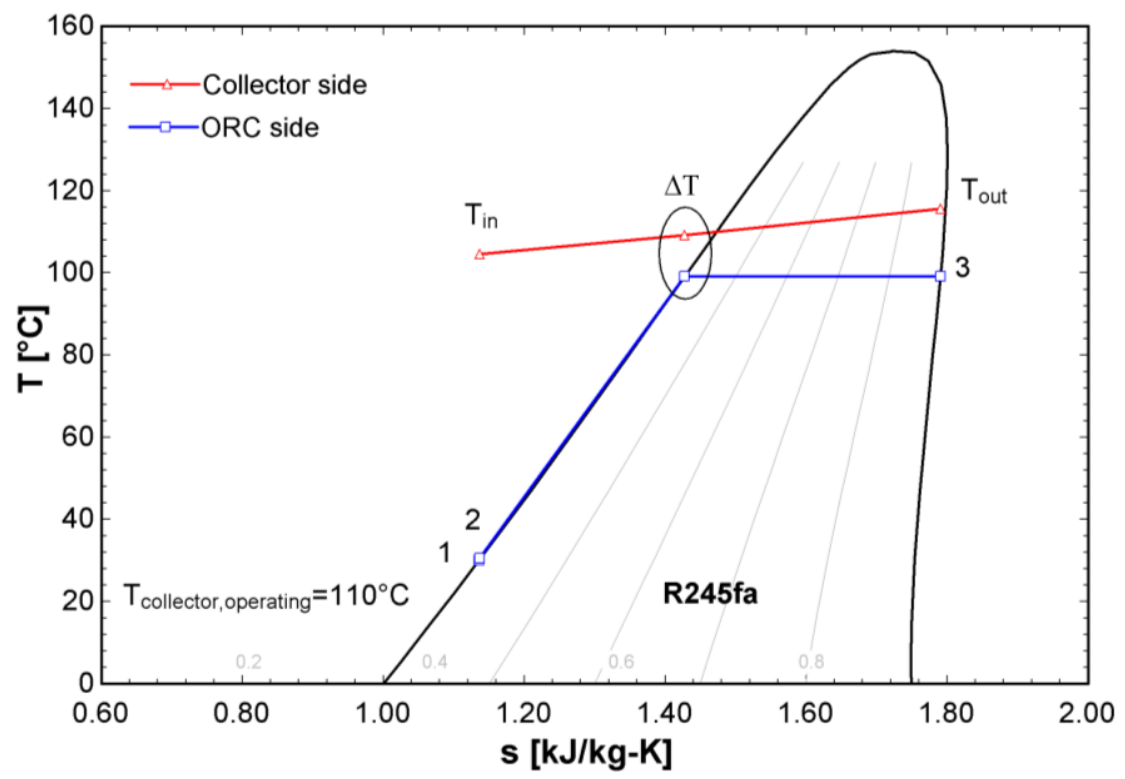

Fig. 8. Pinch temperature difference for steady state analysis

Fig. 9 shows variation of the overall efficiency of system with respect to collector operating temperature for three types of system under low, medium and high solar radiation levels. Fig.9a shows the results for s-ORC. The overall efficiency of s-ORC depends on the collector and ORC efficiency values as calculated from Eq. (20). A higher collector temperature yields a higher evaporation temperature and thus a higher ORC efficiency. However, the overall efficiency does not increase continuously because the collector thermal efficiency reduces at higher temperature. It is more obvious under low solar radiations, for example, the overall efficiency starts to decrease above $115^{\circ} \mathrm{C}$ for $400 \mathrm{~W} / \mathrm{m}^{2}$ solar radiation. For the PV/T-ORC system, the overall efficiency is additionally affected by PV efficiency, aside from the 
collector efficiency and the ORC efficiency. Fig.9b. shows the overall efficiency of a-Si $\mathrm{PV} / \mathrm{T}-\mathrm{ORC}$ system, which increases with temperature until a certain point, for example, the peak efficiency is obtained around $125^{\circ} \mathrm{C}$ under $800 \mathrm{~W} / \mathrm{m}^{2}$ solar radiation. Compared to the a$\mathrm{Si} \mathrm{PV} / \mathrm{T}-\mathrm{ORC}$ system, the poly-Si PV/T-ORC reaches the peak efficiency at lower temperature. As seen in Fig.9c, the overall efficiency starts to reduce by $80{ }^{\circ} \mathrm{C}$ for $400 \mathrm{~W} / \mathrm{m}^{2}$ and by $100^{\circ} \mathrm{C}$ for $800 \mathrm{~W} / \mathrm{m}^{2}$ solar radiation. This trend is owing to the fact that a poly-Si PV efficiency always decreases at higher temperature. We can conclude that the a-Si PV/T-ORC system is more applicable for high temperature applications.
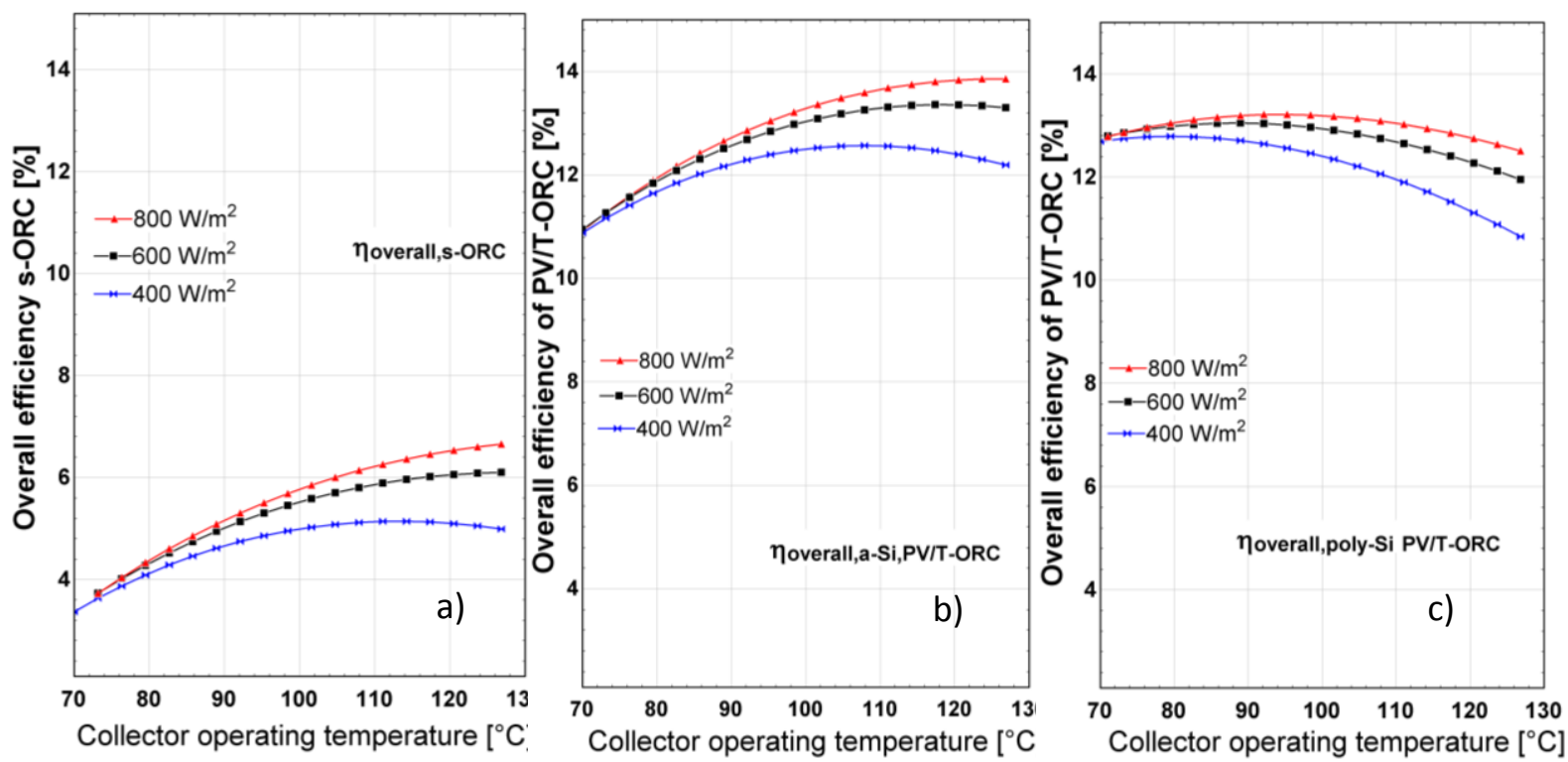

Fig. 9. Overall efficiency variation by the collector operating temperature under different solar radiations.

a) s-ORC, b) a-Si PV/T-ORC, c) poly-Si PV/T-ORC

\subsection{Comparison of transient performance}

After analysing steady operation and noting key observations, this sub-section presents transient simulations of four different systems. In order to carry out transient performance analysis, the components' dimensions must be chosen because the transient performance of system depends on them such as evaporator length, water tank capacity and other specifications. In this study, the system power capacity is chosen to supply sufficient electricity to a small community. As an example, the design power output of the s-ORC system is chosen to be $9.5 \mathrm{~kW}$ assumed as the peak demand for ten houses. Required collector area is calculated according to the steady performance of s-ORC system as discussed earlier. Afterwards, the same specifications of ORC unit and collector area will used in modelling of the a-Si PV/T-ORC and poly-Si PV/T-ORC systems for a fair comparison. The same collector area is also used for the stand-alone poly-si PV system. Detailed information regarding to selection of design parameters for the s-ORC system can be found in our previous study [1]. As water temperature in the tank varies during the day, the evaporation temperature and mass flow rate of working fluid change with time. Saturated vapour is assumed at the evaporator outlet and the rotational speed of expander is kept constant in the simulation. The s-ORC design parameters are given in Table 3. 
Table 3. Design parameters of the s-ORC system

\begin{tabular}{llll}
\hline Collector area & $550 \mathrm{~m}^{2}$ & Tank volume & $87 \mathrm{~m}^{3}$ \\
\hline Collector flow rate & $0.02 \mathrm{~kg} / \mathrm{s}$ & Water flow rate & $2 \mathrm{~kg} / \mathrm{s}$ \\
\hline Evaporator tube length & $51 \mathrm{~m}$ & Condensing temperature & $30^{\circ} \mathrm{C}$ \\
\hline $\begin{array}{l}\text { Evaporator water side } \\
\text { tube diameter }\end{array}$ & $0.3 \mathrm{~m}$ & $\begin{array}{l}\text { Evaporating } \\
\text { temperature }\end{array}$ & $96^{\circ} \mathrm{C}$ \\
\hline $\begin{array}{l}\text { Evaporator refrigerant } \\
\text { side tube diameter }\end{array}$ & $0.012 \mathrm{~m}$ & Power output & $9.5 \mathrm{~kW}$ \\
\hline $\begin{array}{l}\text { Expander rotational } \\
\text { speed }\end{array}$ & $3000 \mathrm{rpm}$ & $\begin{array}{l}\text { Mechanical-to-electrical } \\
\text { efficiency }\end{array}$ & 0.95 \\
\hline
\end{tabular}

To make this comparison more realistic, statistical weather data have been used. These weather data relate to the climate conditions of Istanbul, Turkey. Relevant parameters such as solar irradiance and ambient temperature are obtained from EnergyPlus [47]. In this study, the weather data of two selected days are used to evaluate the proposed system's performance. One selected day has very good solar radiation, while the other is chosen with moderate solar radiation along with relatively low ambient temperature. Fig. 10 shows the used weather data for two chosen days on $14^{\text {th }}$ April and $26^{\text {th }}$ July in Istanbul.
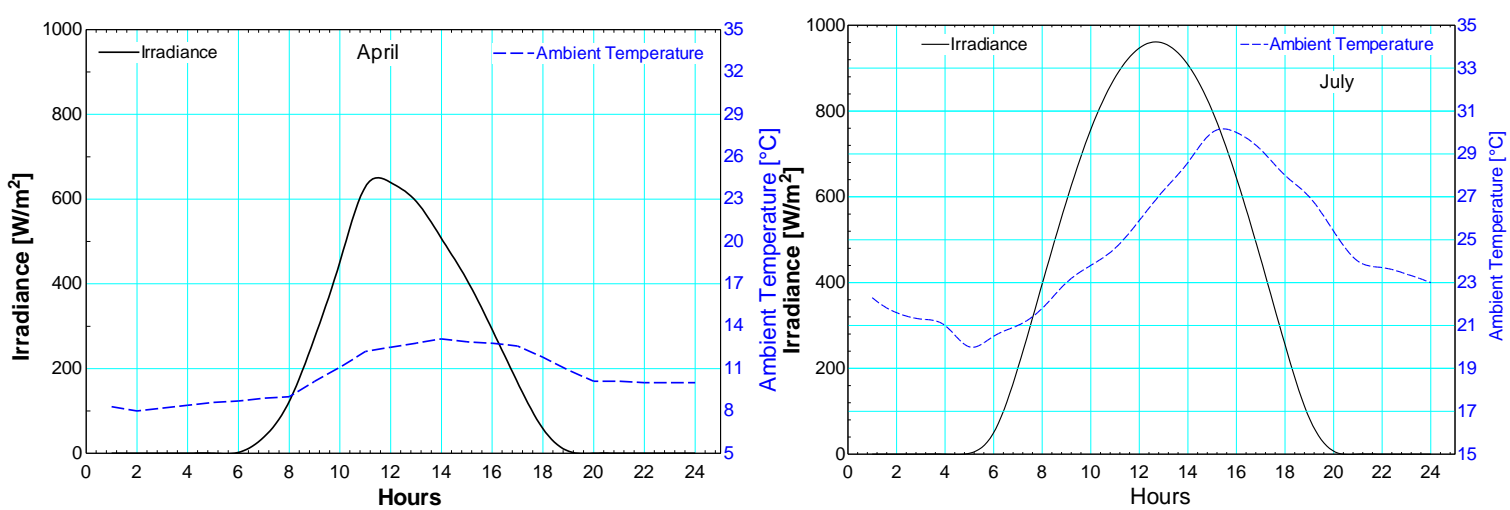

Fig. 10. EnergyPlus weather data for $14^{\text {th }}$ April and $26^{\text {th }}$ July in Istanbul

As the simulation results are given for selected weather data, the initial tank temperature needs to be determined by repeating simulation several times to establish an initial temperature gradient in the tank. To ensure a transient operation not too far from the design conditions, a stop criterion is also defined. The temperature of the fifth element of the tank is the selected parameter in the stop criterion. The setting temperature for stop activation is chosen as $80^{\circ} \mathrm{C}$ and $100^{\circ} \mathrm{C}$ for April and July, respectively. When the stop is activated, the working fluid pump is shut off and the tank is only exposed to heat loss to the environment for the particular simulation. Simulations have been conducted for four different systems, that is, s-ORC, a-Si PV/T-ORC, poly-Si PV/T-ORC and stand-alone poly-Si PV. EFP collectors are used in the first three systems. For the s-ORC system, electricity is only produced by the expander thus system operation is continued throughout the day. While, for the a-Si PV/TORC and poly-Si PV/T-ORC systems, electricity is produced by PV cells during day time and by the ORC using heat from the water tank in the evening and at night. 
Fig.11 shows a comparison of the four different systems according to collector operating temperatures, collector thermal efficiencies and PV electrical efficiencies on $26^{\text {th }}$ July. Collector operating temperature which is the mean temperature of the collector inlet and outlet has an influence on collector performances such as thermal and electrical efficiencies. Therefore, Fig.11a is plotted to compare the collector operating temperatures of the s-ORC, a-Si PV/T-ORC and poly-Si PV/T-ORC systems. Since only the s-ORC consumes stored heat during the daytime, the tank temperature of this system stands lower than others. Thus, its collector operating temperature is lower, which is associated with a better thermal efficiency. It increases from $95^{\circ} \mathrm{C}$ to $105^{\circ} \mathrm{C}$. The poly-Si PV/T collector operating temperature is slightly higher than a-Si PV/T. This is caused by a lower electrical efficiency and thus a better thermal efficiency at a higher operating temperature.

Thermal efficiencies of the collectors are given in Fig. 11b. PV electric efficiencies make the difference for both PV/T systems, as PV conversion reduces thermal efficiency. Therefore, thermal efficiency of the collectors of the s-ORC system is higher than that of PV/T collectors, while due to its lower electrical efficiency at a higher operating temperature the poly-Si PV/T system has a slightly higher thermal efficiency than the a-Si PV/T system.

Fig. 11c shows electrical efficiencies of cells for the a-Si PV/T, poly-Si PV/T and stand-alone PV systems during the day. It is evident that the electrical performance of stand-alone PV is better than PV/T-ORC systems. The electrical efficiency depends on cell temperature; the PV cell temperature is lower in stand-alone PV as the heat generated in the PV cells is dissipated to the ambient via convection. However, in the PV/T-ORC systems, cell temperature is totally dependent on collector operating temperature. Thus, stand-alone PV performance is only affected by ambient conditions. According to Fig. 2, poly-Si cells have lower performance compared to a-Si cells when operating above $98^{\circ} \mathrm{C}$. Since collector operating temperature increases from $110^{\circ} \mathrm{C}$ to $140{ }^{\circ} \mathrm{C}$ in the simulation for the chosen day, the poly-Si cell efficiency decreases to below $6 \%$. In contrast, a-Si cell performance is quite stable and higher around $8 \%$ even at higher operating temperature.

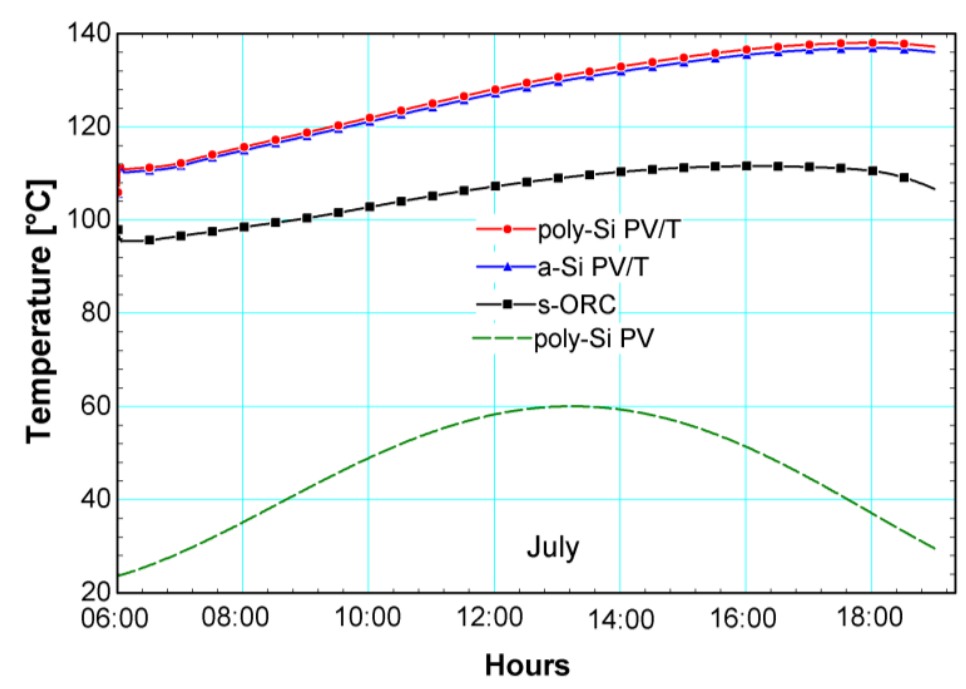



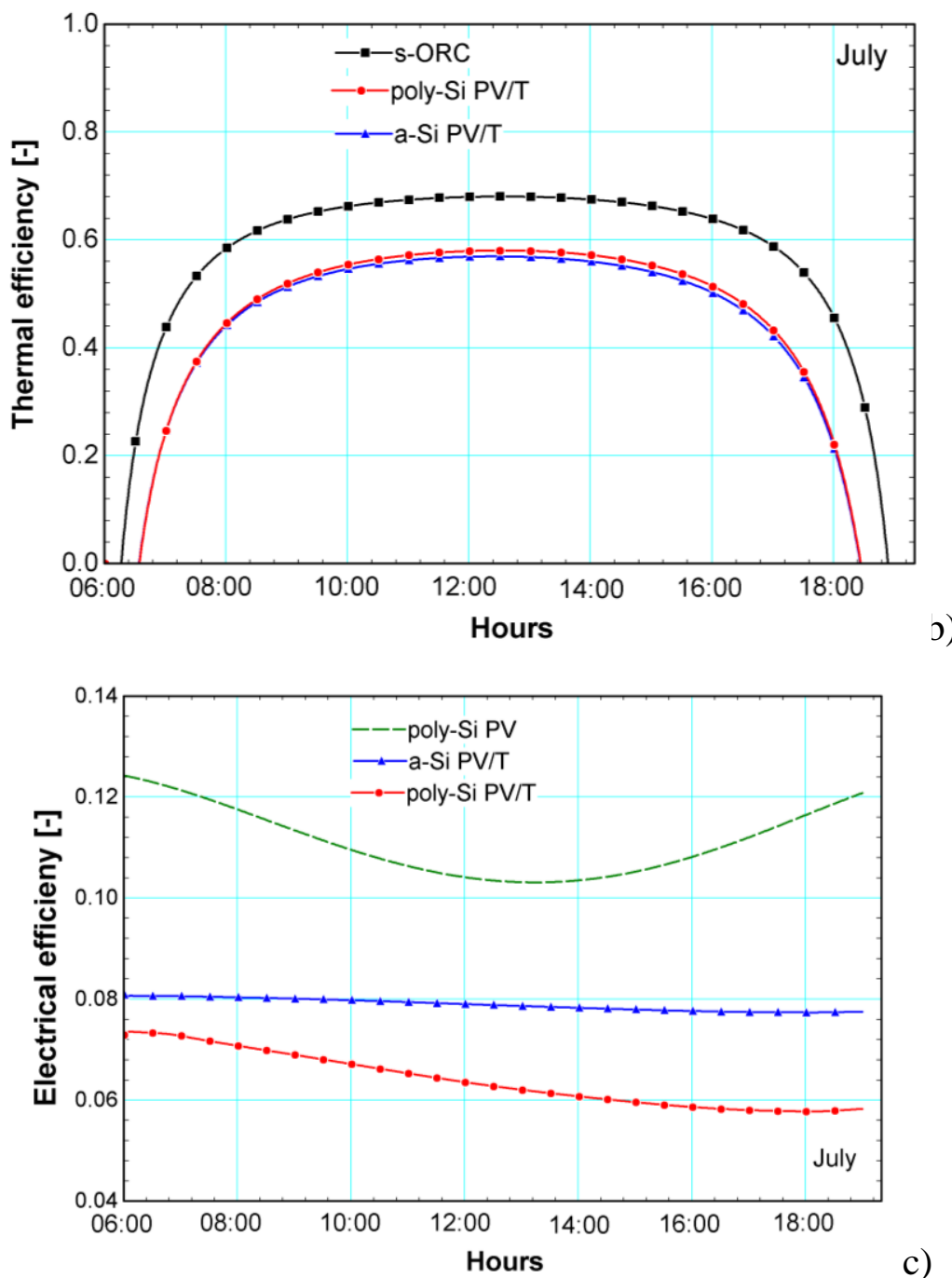

b)

c)

Fig. 11. Comparison of four different systems on $26^{\text {th }}$ July a) Collector operating temperatures, b) Collector thermal efficiencies, c) Collector electrical efficiencies

Fig. 12 shows the comparison of the instant electricity outputs for the four examined systems. As solar radiation is high in July, s-ORC and hybrid systems can produce electricity for 24 hours. A DC-AC conversion efficiency for PV cells was used in calculation of electricity output and a mechanical-to-electrical conversion efficiency for the ORC unit was also considered. The stand-alone poly-Si PV and s-ORC systems have the highest and lowest instant electricity outputs, respectively. Although the stand-alone poly-Si PV system and poly-Si PV/T have the same collector area and same PV cell size, the higher operating temperature of PV/T-ORC causes lower PV electricity output as the collector working fluid is circulated from the water tank. The a-Si PV/T-ORC system produces higher output than the poly-Si PV/T-ORC because a-Si cells have better efficiency at higher operating temperature. Since the s-ORC system only produces electricity via its expander, its performance is lower than others in daytime. After sunset, two PV/T-ORC systems generate higher electricity than the s-ORC because their water tank temperatures can reach a higher level. The reason is that the s-ORC system consumes the solar heat throughout the day, whereas two PV/T-ORC systems charge the water tank during the daytime and start to consume this stored heat after sunset. 


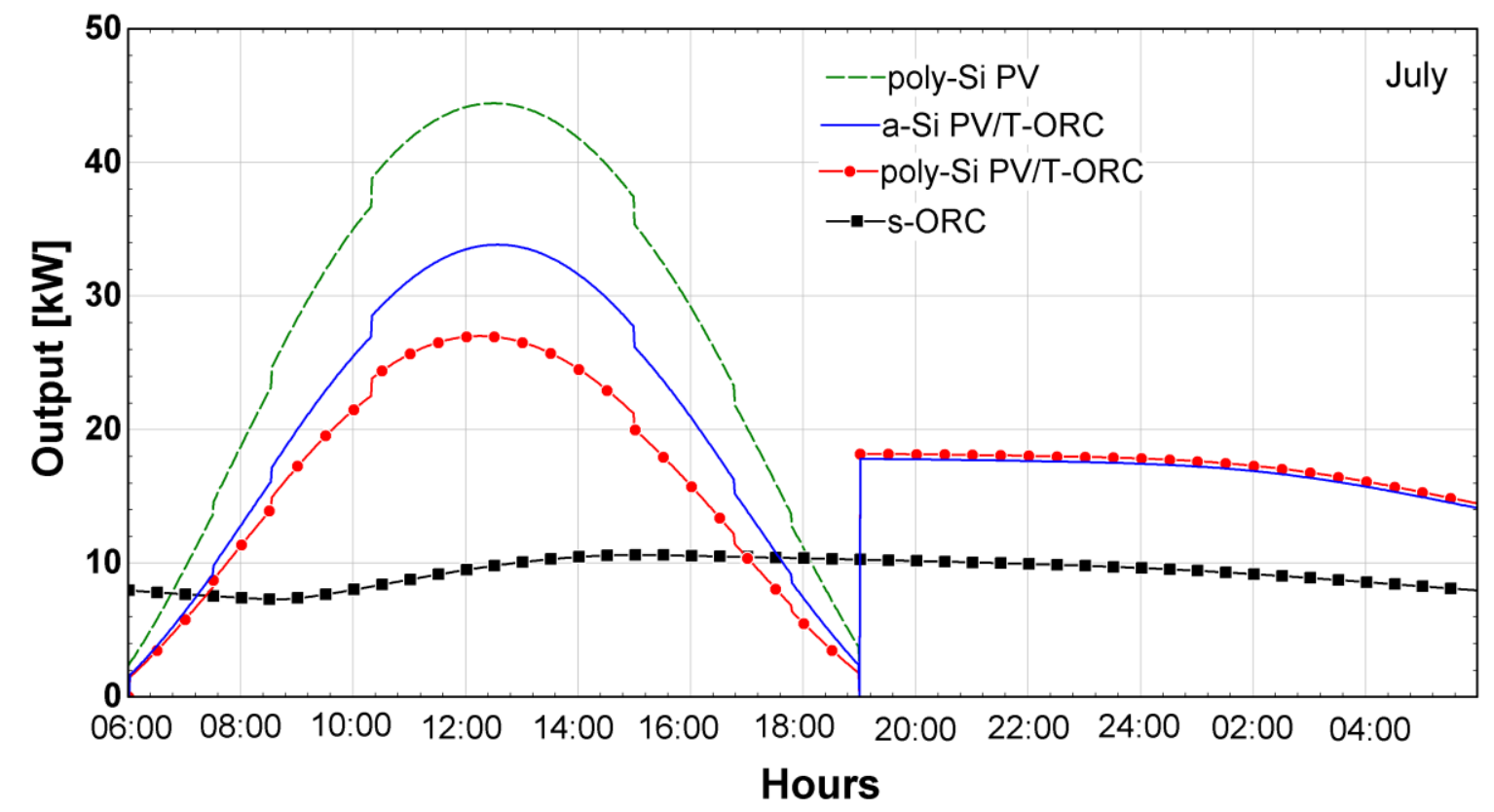

Fig. 12. Comparison of transient electricity outputs of four different systems on $26^{\text {th }} \mathrm{July}$

In order to present a further comparison, Fig.13 is given for four different systems when they are operated on $14^{\text {th }}$ April according to collector operating temperatures, collector thermal efficiencies and PV electrical efficiencies. Fig. 13a shows collector operating temperatures. As expected, the operating temperatures of four different systems are all lower than those in July as the lower solar irradiance does not cause an increase in the tank temperature as high as that in July. It is also seen from the figure that the collector operating temperature of sORC is still lower compared to two PV/T-ORC systems, which have a temperature variation from $85^{\circ} \mathrm{C}$ to $100^{\circ} \mathrm{C}$.

Fig. 13b shows collector thermal efficiencies. Although the collector operating temperatures are lower in April, the performances of four different systems are all worse than those in July because of lower irradiance and lower ambient temperature. Fig. 13c shows electrical efficiencies. The stand-alone poly-Si PV system has a higher performance as a result of lower ambient temperature in April. Referring back to Fig. 2, the poly-Si cells have better performance when operating below $98{ }^{\circ} \mathrm{C}$, which is why the poly-Si PV/T has a higher electrical efficiency until noon when the operating temperature increases from $87^{\circ} \mathrm{C}$ to $100^{\circ} \mathrm{C}$. 

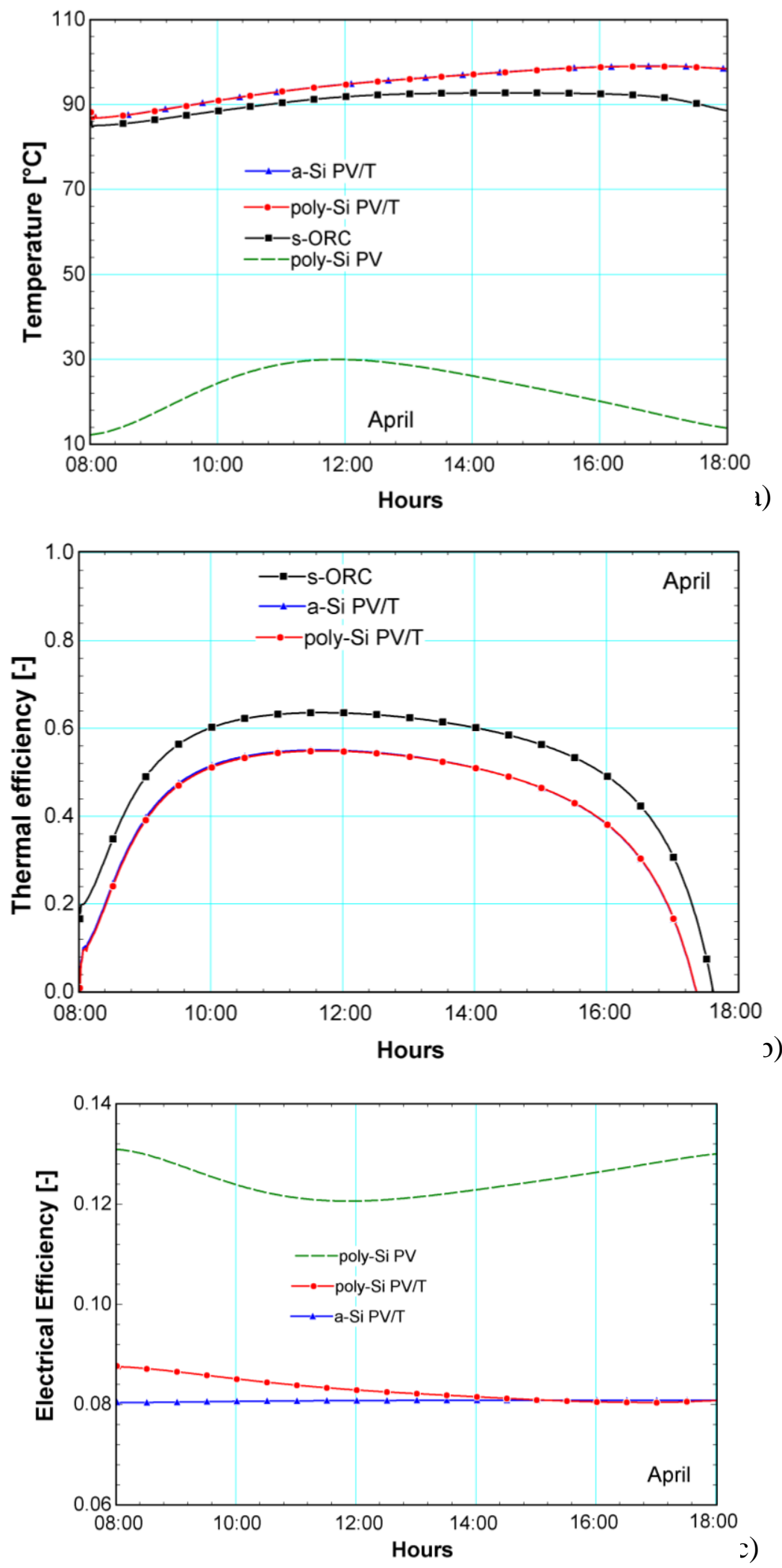

Fig. 13. Comparison of four different systems on $14^{\text {th }}$ April a) Collector operating temperatures, b)Collector thermal efficiencies, c)PV electrical efficiencies 
Fig. 14 shows the comparison of the instant electricity outputs for the four examined systems on $14^{\text {th }}$ April. Since the daily average solar irradiance is weaker and solar time is shorter in April, electricity production is lower for all four different systems compared to July. Moreover, none of the systems can produce electricity for 24 hours. Similar to the results for July, the stand-alone poly-Si PV and s-ORC systems have the highest and lowest electricity outputs, respectively. In Fig. 14, the poly-Si PV/T-ORC system generates slightly higher electricity than the a-Si PV/T-ORC during the daytime due to better electrical efficiency; in comparison, the results for July show that the a-Si PV/T-ORC system produces considerably more. As their collectors have very close operating conditions, the ORC performances of two PV/T-ORC systems are quite close. The PV outputs of two PV/T-ORC systems are also close because both operating temperatures and electrical efficiencies are very close in the achieved temperature range during the daytime. Since the s-ORC system consumes heat continuously, its electricity production ends around 23:00 but two PV/T-ORC systems can continue to produce until 5:00.

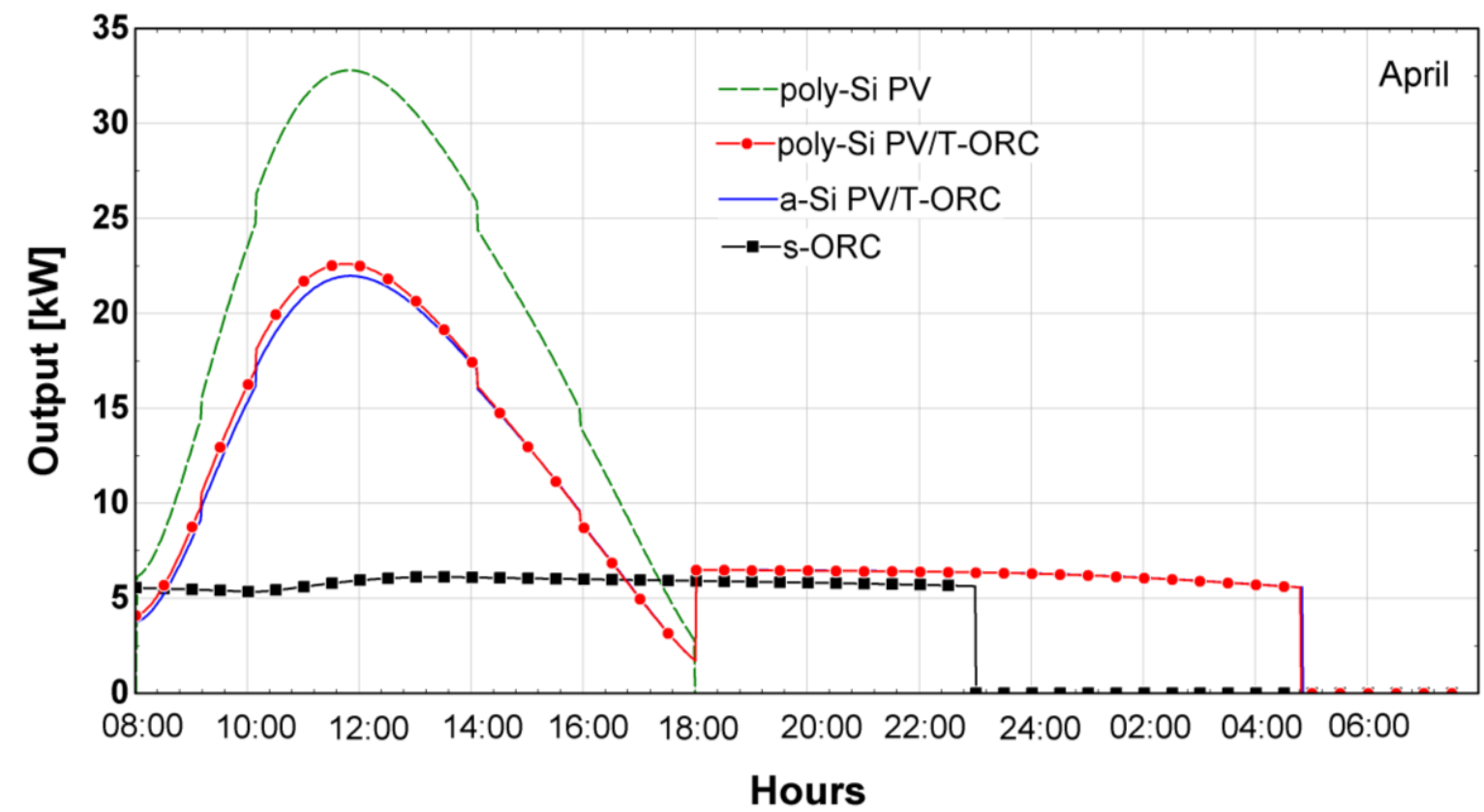

Fig. 14. Comparison of transient electricity outputs of four different systems on $14^{\text {th }}$ April

Cumulative daily performances of four different systems are given in Table 4. Compared to the results for April, the daily produced electricity values are significantly higher in July. The s-ORC system has the worst daily performance for both months. The a-Si PV/T-ORC, polySi PV/T-ORC and stand-alone poly-Si PV systems produce almost same electricity in April. However, the a-Si PV/T-ORC system produces more power in July. As the power output in summer will account for a large proportion of annual electricity yield for these systems, it can be concluded that the PV/T-ORC systems have an advantage over the typical s-ORC and PV systems. For a typical weather condition in July, the a-Si PV/T-ORC system would produce $102.3 \%$ more electricity than the s-ORC system, $23.8 \%$ more than the stand-alone poly-Si PV system and $12 \%$ more than the poly-Si PV/T-ORC system, respectively. 
Table 4. Daily Produced electricity

\begin{tabular}{ccccc}
\hline & s-ORC & a-Si PV/T-ORC & poly-Si PV/T-ORC & poly-Si PV \\
\hline $\begin{array}{c}\text { Daily Output [kWh] in } \\
\text { April }\end{array}$ & 87.27 & 201.74 & 205 & 204.62 \\
\hline $\begin{array}{c}\text { Daily Output [kWh] in } \\
\text { July }\end{array}$ & 223.6 & 452.35 & 403.9 & 365.15 \\
& & & &
\end{tabular}

Aside from power generation, a comparison on the thermo-economic performance between the a-Si PV/T-ORC and the other three systems can be made using the data in Tables 2,3 and 4:

(1) Compared with the poly-Si PV/T-ORC, the a-Si PV/T-ORC has a lower capital cost. The costs of a-Si and poly-Si PV panels are about 0.45-0.53 USD/Watt and 0.8-0.9 USD/Watt, respectively [48]. Given an aperture area of $550 \mathrm{~m}^{2}$, a-Si module efficiency of $6.5 \%$ @ $25{ }^{\circ} \mathrm{C}$, poly-Si module efficiency of $13 \%$ @ $25^{\circ} \mathrm{C}$ and solar irradiance of $1000 \mathrm{~W} / \mathrm{m}^{2}$, the costs of a-Si and poly-Si panels are about 18,000 and 55,000 USD. Owing to its higher yearly output and lower capital cost, the a-Si PV/T-ORC would have a shorter payback time.

(2) Compared with s-ORC, the a-Si PV/T-ORC has a higher capital cost due to the employment of a-Si cells. However, an additional cost of about 18, 000 USD for the cells is relatively low in consideration of the costs of EFP collectors (>137,500 USD for 550 $\mathrm{m}^{2}$, i.e., $>250 \mathrm{USD} / \mathrm{m}^{2}$ ) and ORC module (>1500 USD/kW). Because its power output is 2-3 times higher, the a-Si PV/T-ORC will be more cost-effective.

(3) Compared with the stand-alone PV system, the a-Si PV/T-ORC uses water storage for flexible power generation. If lithium-ion battery of a 6-hour storage capacity is included, the cost of the PV system will be increased by around 45,000 USD according to the market average battery price of $156 \mathrm{USD} / \mathrm{kWh}$ in 2019 [49]. Moreover, the lifetime of battery is about 3-5 years (or 1000 - 1500 cycles). Due to its higher power output and ability to meet the domestic heat demand, the a-Si PV/T-ORC can be more economic.

\section{Conclusion}

In this study, an innovative a-Si PV/T-ORC system has been compared by simulation with the solar ORC, poly-Si PV/T-ORC, stand-alone PV systems, in order to show the merits of the proposed system. Evacuated flat plate (EFP) collectors with good efficiency at mediumto-high temperature are used to provide solar heat to the ORC. Their performance parameters have been compared under steady and transient state conditions. Although the solar ORC system with thermal storage has advantages such as flexible operation and continuous production even at night, its electricity output has been found to be much lower than standalone PV system of the same collection area. Coupling of these two technologies has given promising results as their advantages can be combined, especially with the use of thermal annealing effect and positive temperature coefficient of a-Si PV cells. The following conclusions can be drawn: 
- Under low solar radiation and ambient temperature conditions by using $550 \mathrm{~m}^{2}$ collector area, the poly-Si PV/T-ORC system has a daily electricity output of 205 $\mathrm{kWh}$, followed by stand-alone poly-Si PV (204.62 kWh), a-Si PV/T-ORC (201.74 $\mathrm{kWh})$ and s-ORC (87.27 kWh).

- Two PV/T-ORC systems' daily outputs are almost same as the stand-alone PV system under low solar radiation, however, their electricity production at night via an ORC unit makes them a better option over stand-alone PV systems because a heat storage can be used instead of an electrical battery.

- Under high solar radiation and ambient temperature conditions, the a-Si PV/T-ORC system has a daily power output of $452.35 \mathrm{kWh}$, followed by the poly-Si PV/T-ORC (403.9 kWh), stand-alone poly-Si PV (365.15 kWh) and s-ORC (223.6 kWh).

- Using a-Si cells in the PV/T-ORC system shows favourable results in summer applications, since it can tolerate excessive temperatures with a stable electrical efficiency. Moreover, the a-Si PV/T-ORC system has not only the advantage of power outputs, but it is also expected that the a-Si PV/T-ORC system would reduce the payback time against the s-ORC system. The unique thermal annealing effect of a-Si cells also makes their usage more promising over poly-Si cells in PV/T-ORC applications in terms of their lifetime.

- The proposed a-Si PV/T-ORC has better thermo-economic performance than the poly-Si PV/T-ORC, stand-alone PV and s-ORC systems, especially under the conditions of stronger solar radiation and higher ambient temperature.

\section{ACKNOWLEDGEMENTS}

The authors would like to thank the European Commission for the Marie Curie Fellowship grant (H2020-MSCA-IF-2015-703746).

\section{Nomenclature}

$A_{\text {col }} \quad$ Collector area, $\mathrm{m}^{2}$

$A \quad$ Heat loss term, $\mathrm{W} \mathrm{m}^{-2} \mathrm{~K}^{-1}$

$B \quad$ Heat loss term, $\mathrm{W} \mathrm{m} \mathrm{m}^{-2}$

$c_{p} \quad$ Specific heat, $\mathrm{J} \mathrm{kg}^{-1} \mathrm{~K}^{-1}$

G Solar irradiance, $\mathrm{W} \mathrm{m}^{-2}$

$h \quad$ Specific enthalpy, $\mathrm{J} / \mathrm{kg}$

$\dot{m} \quad$ Mass flow rate, $\mathrm{kg} \mathrm{s}^{-1}$

$M \quad$ Mass, $\mathrm{kg}$

NOCT Normal operating cell temperature ${ }^{\circ} \mathrm{C}$

$\dot{Q} \quad$ Heat rate, $\mathrm{W}$

T Temperature, ${ }^{\circ} \mathrm{C}$

$U \quad$ Overall heat transfer coefficient, $\mathrm{W} \mathrm{m}{ }^{-2} \mathrm{~K}^{-1}$

$v \quad$ Specific volume, $\mathrm{m}^{3} / \mathrm{kg}$

$\dot{W} \quad$ Power, $\mathrm{W}$

$x \quad$ Cover area ratio

\section{Subscripts}

$\begin{array}{cl}\text { ad } & \text { Adapted } \\ a & \text { Ambient } \\ c & \text { Collector } \\ \text { col } & \text { Collector out } \\ c w & \text { Water flow through the } \\ & \text { collector } \\ i & \text { Isentropic } \\ \text { in } & \text { Internal expansion } \\ \text { leak } & \text { Leakage } \\ \text { me } & \text { Mechanical to electricity } \\ r e f & \text { Refrigerant } \\ \text { su } & \text { Supply } \\ s w & \text { Swept volume } \\ s t & \text { Storage } \\ s t, i & \text { i }{ }^{\text {th }} \text { node of storage tank }\end{array}$


Greek letters

$v \quad$ Vapour

$\eta \quad$ Efficiency

$\rho \quad$ Density, $\mathrm{kg} \mathrm{m}^{-3}$ wo
Vapour evaporator

Water outlet of the evaporator Tank

\section{References}

[1] Kutlu C, Li J, Su Y, Pei G, Riffat S. Off-design performance modelling of a solar organic Rankine cycle integrated with pressurized hot water storage unit for community level application. Energy Convers Manag 2018;166:132-45. https://doi.org/10.1016/j.enconman.2018.04.024.

[2] Quoilin S, Orosz M, Hemond H, Lemort V. Performance and design optimization of a low-cost solar organic Rankine cycle for remote power generation. Sol Energy 2011;85:955-66. https://doi.org/10.1016/j.solener.2011.02.010.

[3] Melek D, Erdogan A, Ozgur C. Thermodynamic performance assessment of an integrated geothermal powered supercritical regenerative organic Rankine cycle and parabolic trough solar collectors. Energy 2017;120:306-19. https://doi.org/10.1016/j.energy.2016.11.083.

[4] Zhao L, Zhang Y, Deng S, Ni J, Xu W, Ma M, et al. Solar driven ORC-based CCHP : Comparative performance analysis between sequential and parallel system configurations. Appl Therm Eng 2018;131:696-706. https://doi.org/10.1016/j.applthermaleng.2017.12.028.

[5] Ustaoglu A, Okajima J, Zhang X, Maruyama S. Assessment of a solar energy powered regenerative organic Rankine cycle using compound parabolic involute concentrator. Energy Convers Manag 2019;184:661-70. https://doi.org/10.1016/j.enconman.2019.01.079.

[6] Kosmadakis G, Manolakos D, Papadakis G. Simulation and economic analysis of a $\mathrm{CPV} /$ thermal system coupled with an organic Rankine cycle for increased power generation. Sol Energy 2011;85:308-24. https://doi.org/10.1016/j.solener.2010.11.019.

[7] Tourkov K, Schaefer L. Performance evaluation of a PVT / ORC ( photovoltaic thermal / organic Rankine cycle ) system with optimization of the ORC and evaluation of several PV ( photovoltaic ) materials. Energy 2015;82:839-49.

https://doi.org/10.1016/j.energy.2015.01.094.

[8] Calise F, D'Accadia MD, Vicidomini M, Scarpellino M. Design and simulation of a prototype of a small-scale solar CHP system based on evacuated flat-plate solar collectors and Organic Rankine Cycle. Energy Convers Manag 2015;90:347-63. https://doi.org/10.1016/j.enconman.2014.11.014.

[9] Freeman J, Guarracino I, Kalogirou SA, Markides CN. A small-scale solar organic Rankine cycle combined heat and power system with integrated thermal energy storage. Appl Therm Eng 2017;127:1543-54. https://doi.org/10.1016/j.applthermaleng.2017.07.163. 
[10] Twomey B, Jacobs PA, Gurgenci H. Dynamic performance estimation of small-scale solar cogeneration with an organic Rankine cycle using a scroll expander. Appl Therm Eng 2013;51:1307-16. https://doi.org/10.1016/j.applthermaleng.2012.06.054.

[11] Ramos A, Anna M, Freeman J, Markides CN. Optimisation of a high-e ffi ciency solar-driven organic Rankine cycle for applications in the built environment. Appl Energy 2018;228:755-65. https://doi.org/10.1016/j.apenergy.2018.06.059.

[12] Freeman J, Hellgardt K, Markides CN. Working fluid selection and electrical performance optimisation of a domestic solar-ORC combined heat and power system for year-round operation in the UK. Appl Energy 2017;186:291-303. https://doi.org/10.1016/j.apenergy.2016.04.041.

[13] Kutlu C, Li J, Su Y, Wang Y, Pei G, Riffat S. Annual performance simulation of a solar cogeneration plant with sensible heat storage to provide electricity demand for a small community: A transient model. Hittite J Sci Eng 2019;6:75-81. https://doi.org/10.17350/HJSE19030000125.

[14] Gao G, Li J, Cao J, Yang H, Pei G, Su Y. The study of a seasonal solar cchp system based on evacuated flat- plate collectors and organic rankine cycle. Therm Sci 2019. https://doi.org/https://doi.org/10.2298/TSCI180804101G.

[15] Aste N, Leonforte F, Pero C Del. Design , modeling and performance monitoring of a photovoltaic - thermal ( PVT ) water collector. Sol Energy 2015;112:85-99. https://doi.org/10.1016/j.solener.2014.11.025.

[16] Kumar M, Kumar A. Performance assessment and degradation analysis of solar photovoltaic technologies: A review. Renew Sustain Energy Rev 2017;78:554-87. https://doi.org/10.1016/j.rser.2017.04.083.

[17] Sharma A. A comprehensive study of solar power in India and World. Renew Sustain Energy Rev 2011;15:1767-76. https://doi.org/10.1016/j.rser.2010.12.017.

[18] Fraunhofer. Photovoltaics report 2016:1-43. https://doi.org/26.05.2014.

[19] Li J, Ren X, Yuan W, Li Z, Pei G, Su Y, et al. Experimental study on a novel photovoltaic thermal system using amorphous silicon cells deposited on stainless steel. Energy 2018;159:786-98. https://doi.org/10.1016/j.energy.2018.06.127.

[20] King DL, Kratochvil JA, Boyson WE. Temperature coefficients for PV modules and arrays: measurement methods, difficulties, and results. Proc 25th IEEE Photovolt Spec Conf 1997:1183-6.

[21] Guo C, Ji J, Sun W, Ma J, He W, Wang Y. Numerical simulation and experimental validation of tri-functional photovoltaic / thermal solar collector. Energy 2015;87:470 80. https://doi.org/10.1016/j.energy.2015.05.017.

[22] Gang P, Huide F, Huijuan Z, Jie J. Performance study and parametric analysis of a novel heat pipe PV / T system. Energy 2012;37:384-95. https://doi.org/10.1016/j.energy.2011.11.017.

[23] Hanergy. Thin-film Solar Power Generation 2015. http://www.hanergy.com/en/industry/industry_310.html.

[24] Amorphous-Silicon-Thin-Film-Solar-Cells-Offer-Significant-Opportunities-as-BetterTechnologies-Evolve 2019. https://www.globenewswire.com/news- 
release/2019/05/14/1823568/0/en/Amorphous-Silicon-Thin-Film-Solar-Cells-OfferSignificant-Opportunities-as-Better-Technologies-Evolve.html.

[25] Ren X, Li J, Hu M, Pei G, Jiao D, Zhao X, et al. Feasibility of an innovative amorphous silicon photovoltaic / thermal system for medium temperature applications. Appl Energy 2019;252:113427. https://doi.org/10.1016/j.apenergy.2019.113427.

[26] Nikolaeva-Dimitrova M, Kenny RP, Dunlop ED, Pravettoni M. Seasonal variations on energy yield of a-Si, hybrid, and crystalline Si PV modules. Prog Photovoltaics Res Appl 2010;18:311-20. https://doi.org/10.1002/pip.918.

[27] Staebler DL, Wronski CR. Reversible conductivity changes in discharge-produced amorphous Si. Appl Phys Lett 1977;31:292-4. https://doi.org/10.1063/1.89674.

[28] Sofiane K, Silvestre S, Nofuentes G, Torres-ramírez M, Chouder A, Guasch D. Characterization of degradation and evaluation of model parameters of amorphous silicon photovoltaic modules under outdoor long term exposure. Energy 2016;96:23141. https://doi.org/10.1016/j.energy.2015.12.054.

[29] Solar frontier n.d. https://www.solar-frontier.eu/en/news/usefulinformation/detail/wussten-sie-das-schon-der-staebler-wronski-effekt-reduziert-dieleistung-von-solarmodulen-auf-basis-von-amorphem-silizium-die-cis-technologie-istdavon-nicht-betroffen/ (accessed November 20, 2019).

[30] Pathak MJM, Girotra K, Harrison SJ, Pearce JM. The effect of hybrid photovoltaic thermal device operating conditions on intrinsic layer thickness optimization of hydrogenated amorphous silicon solar cells. Sol Energy 2012;86:2673-7. https://doi.org/10.1016/j.solener.2012.06.002.

[31] Pathak MJM, Pearce JM, Harrison SJ. Solar Energy Materials \& Solar Cells Effects on amorphous silicon photovoltaic performance from high-temperature annealing pulses in photovoltaic thermal hybrid devices. Sol Energy Mater Sol Cells 2012;100:199203. https://doi.org/10.1016/j.solmat.2012.01.015.

[32] Mattei M, Notton G, Cristofari C, Muselli M, Poggi P. Calculation of the polycrystalline PV module temperature using a simple method of energy balance. Renew Energy 2006;31:553-67. https://doi.org/10.1016/j.renene.2005.03.010.

[33] Ungureşan P, Petreuş D, Pocola A, BĂlan M. Potential of Solar ORC and PV Systems to Provide Electricity under Romanian Climatic Conditions. Energy Procedia 2016;85:584-93. https://doi.org/10.1016/j.egypro.2015.12.248.

[34] Mulcué-Nieto LF, Mora-López L. A new model to predict the energy generated by a photovoltaic system connected to the grid in low latitude countries. Sol Energy 2014;107:423-42. https://doi.org/10.1016/j.solener.2014.04.030.

[35] Santiago I, Trillo-Montero D, Moreno-Garcia IM, Pallarés-López V, Luna-Rodríguez JJ. Modeling of photovoltaic cell temperature losses: A review and a practice case in South Spain. Renew Sustain Energy Rev 2018;90:70-89. https://doi.org/10.1016/j.rser.2018.03.054.

[36] Li J, Li P, Pei G, Ji J, Alvi JZ, Xia L. A Novel Hybrid Solar Power Generation System Using a-Si Photovoltaic / Thermal Collectors and Organic Rankine Cycle. Proc. 3rd Int. Semin. ORC Power Syst., 2015, p. 1-10.

[37] TVPSOLAR. HT Power product datasheet 2013;2013. 
http://www.tvpsolar.com/files/pagine/HT-Power Datasheet (v4.2x)(ver3).pdf.

[38] Duffie JA, Beckman WA. Solar Engineering of Thermal Processes. John Wiley; 2013.

[39] Bellos E, Tzivanidis C, Symeou C, Antonopoulos KA. Energetic , exergetic and financial evaluation of a solar driven absorption chiller - A dynamic approach. Energy Convers Manag 2017;137:34-48. https://doi.org/10.1016/j.enconman.2017.01.041.

[40] Kutlu C, Tahir M, Li J, Wang Y, Su Y. A study on heat storage sizing and fl ow control for a domestic scale solar-powered organic Rankine cycle-vapour compression refrigeration system. Renew Energy 2019;143:301-12. https://doi.org/10.1016/j.renene.2019.05.017.

[41] Lemort V, Quoilin S, Cuevas C, Lebrun J. Testing and modeling a scroll expander integrated into an Organic Rankine Cycle. Appl Therm Eng 2009;29:3094-102. https://doi.org/10.1016/j.applthermaleng.2009.04.013.

[42] Dickes R, Dumont O, Daccord R, Quoilin S, Lemort V. Modelling of organic Rankine cycle power systems in off-design conditions : An experimentally-validated comparative study. Energy 2017;123:710-27. https://doi.org/10.1016/j.energy.2017.01.130.

[43] Giuffrida A. Modelling the performance of a scroll expander for small organic Rankine cycles when changing the working fluid. Appl Therm Eng 2014;70:1040-9. https://doi.org/10.1016/j.applthermaleng.2014.06.004.

[44] Hu D, Zheng Y, Wu Y, Li S, Dai Y. Off-design performance comparison of an organic Rankine cycle under different control strategies. Appl Energy 2015;156:268-79. https://doi.org/10.1016/j.apenergy.2015.07.029.

[45] Li J, Zeb J, Pei G, Ji J, Li P, Fu H. Effect of working fluids on the performance of a novel direct vapor generation solar organic Rankine cycle system. Appl Therm Eng 2016;98:786-97. https://doi.org/10.1016/j.applthermaleng.2015.12.146.

[46] Bellos E, Tzivanidis C. Parametric analysis and optimization of a solar driven trigeneration system based on ORC and absorption heat pump. J Clean Prod 2017;161:493-509. https://doi.org/10.1016/j.jclepro.2017.05.159.

[47] Crawley DB, Lawrie LK, Army US, Champaign C, Curtis I, Pedersen O, et al. EnergyPlus: Energy Simulation Program. ASHRAE J 2000;42:49-56. https://doi.org/10.1.1.122.6852.

[48] Solar Panel Costs n.d. https://solarenergyforus.com/solar-panels-cost/ (accessed April 21, 2020).

[49] Battery Pack prices n.d. https://www.pveurope.eu/News/Energy-Storage/Battery-packprices-will-fall-below-100-kWh (accessed May 1, 2020). 